\title{
PERKEMBANGAN GONAD BULU BABI (Tripneustes gratilla) DI KEPULAUAN SPERMONDE, SULAWESI SELATAN
}

\author{
Gunarto*) dan Edi Setiabudi")
}

\begin{abstract}
ABSTRAK
Gonad bulu babi Tripneustes gratilla pada stadia perkembangan merupakan gonad yang banyak dicari oleh konsumen karena bertekstur kompak, padat, tidak berlendir, dan berwarna kuning cerah. Penelitian ini bertujuan untuk mengetahui kondisi gonad bulu babi yang ditangkap di perairan Kepulauan Spermonde. Untuk itu sebanyak 8-10 individu bulu babi ditangkap di daerah padang lamun Kepulauan Spermonde setiap bulan. Sampel kemudian dibawa ke laboratorium. Setelah sampel diukur secara morfometrik dan volumetrik, gonadnya diambil, sebagian difiksasi dengan larutan Bouin untuk selanjutnya dibuat preparat histologi. Preparat histologi dianalisis untuk menentukan tingkat perkembangan gonad yang meliputi stadia perkembangan, matang, dan pijah. Untuk mendukung data yang diperoleh dari analisis kondisi gonad juga dihitung nilai indeks gonad dan analisis proksimat (protein, lemak, dan serat). Hasil penelitian menunjukkan bahwa terdapat variasi perkembangan gonad dari sampel yang diambil pada musim kemarau (Juli-Oktober) dengan stadia berkembang paling tinggi (30\%) dari populasi yaitu pada sampel bulan Agustus dan September 1999. Pada sampel yang diambil pada musim hujan (Nopember-Desember) 100\% gonad dalam stadia berkembang. Nilai indeks gonad paling tinggi diperoleh pada sampel bulan Oktober 1999 di mana $62,5 \%$ sampel dalam keadaan matang gonad. Hasil analisis proksimat menunjukkan bahwa kandungan protein gonad $(56,68 \%)$ dalam stadia berkembang lebih tinggi dibanding protein gonad $(44,69 \%)$ pada stadia matang.
\end{abstract}

\section{ABSTRACT: The gonadal development of sea urchin, Tripneustes gratilla from the water off Spermonde Island. By: Gunarto and Edi Setiabudi}

Developing gonads of sea urchin (Tripneustes gratilla) are highly marketable because of their characteristics such as: compact texture, no mucous, and bright yellow colour. This research was conducted to study the condition of sea urchin collected from the waters off Spermonde Island. For this study, about 8-10 individuals of sea urchins were collected monthly from seagrass bed. Samples were taken to the laboratory to analyze the morphometric and volumetric parameters prior to sectioning of the gonad. For histological analysis, part of the gonad was immersed into the Bouin solution for fixation to determine the gonadal maturity level, which can be classified into three stages i.e. developed, matured, and spawned. The gonadal index value and proximate (protein, fatty acids, and fiber) were also analyzed. The results showed that there were variations in the gonadal stages of the samples collected during the dry season (July-October 1999) with the highest gonadal condition (30\%) was in the developed stage in August and September 1999. Whereas, for the samples collected during the rainy season (November and December 1999), all (100\%) were at the developed stage. The highest gonadal index value was obtained in October 1999 where $62.5 \%$ of the population were at matured stage. The proximate analysis showed that gonads at the developed stage had higher protein content $(56.68 \%)$ than the matured stage $(44.69 \%)$

KEYWORDS: gonadal development, gonadal index, proximate analysis, sea urchin

\section{PENDAHULUAN}

Gonad bulu babi telah dikonsumsi secara luas oleh masyarakat Jepang, Eropa, Amerika Selatan, Amerika Serikat, dan Kanada (Chasanah et al., 1997). Di Filippina terutama di daerah Pangasinan, sejak tahun 1970 eksploitasi bulu babi ( $T$. gratilla) telah terjadi tangkap lebih akibat penangkapan yang intensif untuk diambil gonadnya sebagai komoditas ekspor (Juinio-Menez et al., 1998). Di Indonesia khususnya di Bali, gonad bulu babi tersebut juga pernah dieksploitasi sebagai komoditas yang dapat mendatangkan devisa

\footnotetext{
Peneliti pada Balai Penelitian Pantai, Maros

“) Peneliti pada Pusat Riset Perikanan Budi Daya, Jakarta
}

negara yaitu sebesar AS \$2900 (Dinas Perikanan Dati I Bali, 1985). Sedangkan di daerah lainnya gonad bulu babi hanya dikonsumsi oleh masyarakat tertentu, misalnya masyarakat di Kabupaten Sinjai, Bulukumba, dan Selayar di Sulawesi Selatan serta masyarakat di Kepulauan Maluku. Beberapa spesies bulu babi yang terdapat di perairan Indonesia, adalah Echinotrix sp, Diadema setosum, Echinometra mathaei, Salmacis sp (Nontji, 1987).

Kepulauan Spermonde di Sulawesi Selatan terdiri dari gugusan karang dan padang lamun di 
Tabel 2. Persentase tingkat perkembangan gonad bulu babi ( $T$. gratilla) yang ditangkap dari perairan kepulauan Spermonde

Table 2. Percentage of gonadal development of sea urchin (T. gratilla) caught in Spermonde Island

\begin{tabular}{lllllll}
\hline $\begin{array}{l}\text { Ukuran } \\
\text { Size }\end{array}$ & $\begin{array}{l}\text { Juli } \\
\text { July } \\
\text { (Karanrang) }\end{array}$ & $\begin{array}{l}\text { Agustus } \\
\text { August } \\
\text { (Br. Lompo) }\end{array}$ & $\begin{array}{l}\text { September } \\
\text { September }\end{array}$ & $\begin{array}{l}\text { Oktober } \\
\text { October } \\
\text { (Br. Lompo) }\end{array}$ & $\begin{array}{l}\text { Nopember } \\
\text { November }\end{array}$ & $\begin{array}{l}\text { Desember } \\
\text { December }\end{array}$ \\
\hline $\begin{array}{l}\text { Tinggi cangkang (mm) } \\
\text { Test hight (mm) }\end{array}$ & $40-80$ & $36-51$ & $35-51$ & $50-61$ & $27,2-36,4$ & 29,2-43 \\
Diameter cangkang (mm) & $72-90$ & $57-77$ & $68-77$ & $86-94$ & $47,4-66$ & $54,5-66,1$ \\
$\begin{array}{l}\text { Test diameter (mm) } \\
\text { Berat individu (g) } \\
\text { Individual Weight }(\mathrm{g})\end{array}$ & $100-260$ & $35-172$ & $81-172$ & $148-331$ & $41,4-110,9$ & $49,1-153$ \\
\hline
\end{tabular}

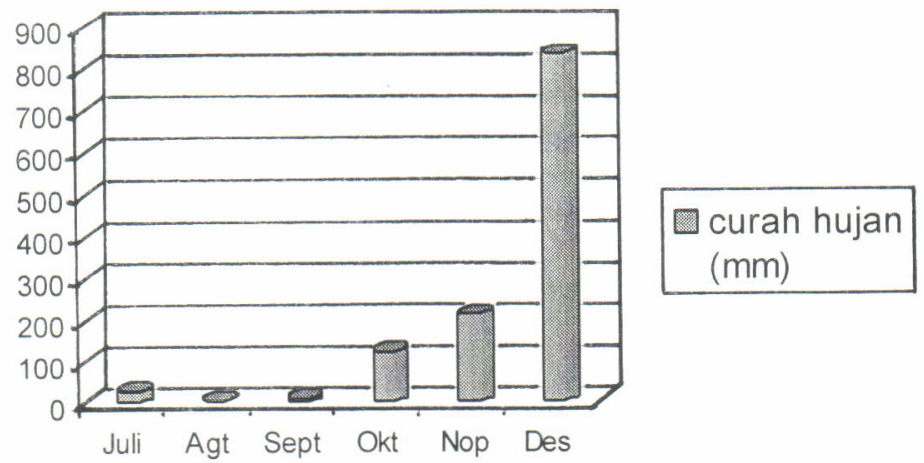

Gambar 1. Data curah hujan dari Stasiun Poatere, Makassar.

Figure 1. Rain fall data obtained from Poatere Station, Makassar.

Oktober 1999 telah terjadi pemijahan secara massal pada bulu babi di perairan Pulau Barang Lompo yang berlanjut dengan terjadinya sinkronisasi pertumbuhan gonad pada bulan Nopember dan Desember 1999.

Berdasarkan uji organoleptik, gonad yang mempunyai nilai ekonomis tinggi dan menarik pasar adalah yang kompak, berwarna kuning atau oranye, dan bertekstur kasar, yang biasanya diperoleh pada stadia berkembang. Pada musim kemarau (Juli-Oktober 1999) gonad pada stadia berkembang didapatkan hanya $10 \%$ dari populasi bulu babi dari Pulau Karanrang pada bulan Juli 1999; 30\% dari Pulau Barang Lompo dan 30\% dari Pulau Barang Cadi yang masing-masing diperoleh pada bulan Agustus dan September 1999, serta $12,5 \%$ dari Pulau Barang Lompo diperoleh pada bulan Oktober 1999. Sedangkan pada musim hujan (Nopember-Desember 1999) gonad pada stadia berkembang diperoleh hingga 100\% dari Pulau Barang Lompo.

Indeks gonad digunakan untuk memperoleh nilai relatif kondisi reproduksi hewan yang terdiri dari berbagai ukuran, sehingga perubahanperubahan kondisinya dapat diperbandingkan dari waktu ke waktu (Giese \& Pearse, 1974). Selanjutnya Bernard (1977) mengemukakan bahwa indeks gonad bukanlah produk gametogenesis tetapi berhubungan dengan akumulasi glikogen yang mencapai 13\% dari berat gonad. Sedangkan menurut Darsono (1983) fluktuasi nilai indeks gonad berkaitan dengan kondisi gonad hewan yang bersangkutan.

Nilai indeks gonad (IG) dari penelitian ini dapat dilihat pada Tabel 3. Nilai IG gonad $T$. gratilla dar bulan Juli hingga Desember 1999 berfluktuasi, yakni tertinggi $(6,18 \pm 1,35)$ diperoleh pada sampel bulan Oktober 1999 dari Pulau Barang Lompo. $62,5 \%$ dari sampel dalam kondisi matang gonad kemudian disusul oleh masing-masing sampel dari Barang Lompo $(5,45 \pm 1,52)$, Karanrang $(4,93 \pm$ $1,6)$, dan yang terendah dari Pulau Barang Cadi $(2,79 \pm 1,75)$, karena $40 \%$ dari sampel gonad dalam kondisi pijah. Terlihat ada kesesuaian antara nilai indeks gonad (IG) dengan puncak matang gonad, yakni persentase puncak matang gonad tinggi maka nilai indeks gonad juga tinggi. Pada bulu babi Diadema setosum di Pulau Pari, Kepulauan Seribu Jakarta, nilai indeks gonad berfluktuasi antara 2,8 hingga 20,4 (Darsono, 1983) 
Tabel 3. Indeks gonad bulu babi ( $T$. gratilla) yang ditangkap dari perairan Kepulauan Spermonde

Table 3. Gonadal Index of sea urchin ( $T$. gratilla) caught from Spermonde Island waters

\begin{tabular}{rlrrrr}
\hline $\begin{array}{l}\text { Juli } \\
\text { July } \\
\text { (Karanrang) }\end{array}$ & $\begin{array}{l}\text { Agustus } \\
\text { August } \\
\text { (Br.Lompo) }\end{array}$ & $\begin{array}{l}\text { September } \\
\text { September } \\
\text { (Br. Cadi) }\end{array}$ & $\begin{array}{l}\text { Oktober } \\
\text { October } \\
\text { (Br. Lompo) }\end{array}$ & $\begin{array}{l}\text { Nopember } \\
\text { November } \\
\text { (Br. Lompo) }\end{array}$ & $\begin{array}{l}\text { Desember } \\
\text { December } \\
\text { (Br. Lompo) }\end{array}$ \\
\hline $4,93 \pm 1,6$ & $5,41 \pm 2,44$ & $2,79 \pm 1,65$ & $6,18 \pm 1,35$ & $4.70 \pm 2,05$ & $5,45 \pm 1,52$ \\
\hline
\end{tabular}

Hasil analisis proksimat gonad bulu babi dalam keadaan kering ditunjukan pada Tabel 4. Dari Tabel 4 dapat dilihat bahwa sampel bulu babi dengan stadia matang gonad sebanyak $62,5 \%$ dari populasi ternyata mempunyai kandungan protein lebih rendah $(44,69 \%)$, dibanding dengan sampel bulu babi yang $100 \%$ populasinya dalam kondisi gonad stadia berkembang, yaitu dengan kandungan protein mencapai 56,68\%. Hasil penelitian terdahulu pada bulu babi $T$. gratilla di perairan pantai Laerngengas dan Tamadan, Kabupaten Tual Maluku Tenggara, yang dipanen pada bulan Oktober 1995 dan Juni 1996, saat itu kondisi gonad pada stadia matang, kandungan proteinnya mencapai 51,8\% (Chasanah \& Andamari, 1997). Perbedaan tersebut kemungkinan karena sebagian protein pada gonad stadia matang telah dirubah menjadi lemak, tidak demikian pada gonad stadia berkembang. Hal ini bisa dilihat pada kandungan lemak yang lebih tinggi $(13,16 \%)$ pada gonad dalam stadia matang, dibanding pada gonad dalam stadia berkembang $(5,73 \%)$.

Data kandungan air dalam gonad cukup rendah $(4,09-5,42 \%)$, hal ini karena sampel gonad sebelum dianalisa dikeringkan terlebih dahulu di dalam oven pada suhu $60^{\circ} \mathrm{C}$ selama 48 jam sampai mencapai berat gonad stabil.

Tabel 4. Analisis proksimat gonad kering bulu babi ( $T$. gratilla) stadia matang dan stadia perkembangan

Table 4. Proximates analysis of dried sea urchin gonad (T. gratilla) in mature and develop stages

\begin{tabular}{lll}
\hline $\begin{array}{l}\text { Parameter } \\
\text { Parameter }\end{array}$ & $\begin{array}{l}\text { Stadia gonad matang } \\
\text { Matured }\end{array}$ & $\begin{array}{l}\text { Stadia gonad berkembang } \\
\text { Developed }\end{array}$ \\
\hline $\begin{array}{l}\text { Protein (\%) } \\
\text { Protein (\%) }\end{array}$ & 44,69 & 56,68 \\
$\begin{array}{l}\text { Lemak (\%) } \\
\text { Fat (\%) }\end{array}$ & 13,16 & 5,73 \\
$\begin{array}{l}\text { Air (\%) } \\
\text { Water (\%) }\end{array}$ & 5,42 & 5,12 \\
$\begin{array}{l}\text { Abu (\%) } \\
\text { Ashes (\%) }\end{array}$ & 10,26 & 13,26 \\
$\begin{array}{l}\text { Serat kasar (\%) } \\
\text { Fibrous part (\%) }\end{array}$ & 5,51 & 4,25 \\
$\begin{array}{l}\text { Ekstrak Nitrogen Bebas (ENB)(\%) } \\
\text { Nitrogen Free Extract (NFE) (\%) }\end{array}$ & 20,96 & 14,96 \\
\hline
\end{tabular}

Data kualitas air di Kepulauan Spermonde di mana bulu babi $T$. gratilla ditangkap yaitu pada bulan Juli hingga awal Oktober salinitas cukup stabil yaitu 35 ppt karena sedang berlangsung musim kemarau. Keadaan salinitas yang cukup stabil tersebut menyebabkan tidak ada sinkronisasi aktivitas biologi bulu babi, sehingga diperoleh bulu babi dalam satu populasi pada kondisi gonad yang bervariasi yaitu stadia berkembang (10-30\%), stadia matang $(30-62,5 \%)$ dan stadia pijah (10$40 \%$ ). Dengan demikian puncak-puncak kondisi gonad bulu babi berada pada stadia matang gonad yaitu pada bulan Juli di perairan Pulau Karanrang $(60 \%)$, bulan Agustus di perairan Pulau Barang Lompo (60\%), dan pada bulan Oktober di perairan Pulau Barang Lompo (62,5\%) terjadi pada musim kemarau. Sedangkan pada bulan NopemberDesember telah terjadi penurunan salinitas sampai 33 ppt karena sedang berlangsung musim hujan. Gunarto \& Wong (1994) melaporkan bahwa penurunan salinitas telah memacu pemijahan secara massal pada tiram di muara Sungai Merbok, Malaysia. Selanjutnya Starr \& Himmelman (1993) mengemukakan bahwa faktor lingkungan 
perairan terutama salinitas, suhu, amplitudo pasang surut dan kandungan klorofil mempengaruhi pemijahan bulu babi hijau Strongilocentrotus droebachiensis, di estuari St. Lawrence, Kanada

Faktor perubahan lingkungan perairan disebabkan karena mulai berlangsungnya musim penghujan tersebut diduga sebagai pemacu terjadinya pemijahan secara massal pada bulu babi T. gratilla di Kepulauan Spermonde. Berdasarkan hasil analisis kualitas air diperoleh bahwa kandungan nitrit dan amoniak masih dalam taraf yang wajar untuk mendukung kehidupan organisme akuatik yaitu masing-masing pada kisaran 0,0109-0,0136 ppm dan 0,0174-0,0228 ppm, pH pada kisaran 7,25-7,71 dan bahan organik total pada kisaran 6,68-13,39 ppm.

Tabel 5. Kisaran kualitas air di perairan Kepulauan Spermonde

Table 5. The range of water quality in Spermonde Island waters

\begin{tabular}{lc}
\hline Parameter & Kisaran Nilai \\
Parameter & $0,0109-0,0136$ \\
\hline Nitrit $(\mathrm{ppm}) /$ Nitrite $(\mathrm{ppm})$ & $0,0174-0,0228$ \\
Amonium $\left(\mathrm{NH}_{3}-\mathrm{N}\right)(\mathrm{ppm})$ & $7,25-7,71$ \\
$\mathrm{pH}$ & $6,68-13,39$ \\
$\mathrm{BOT}(\mathrm{ppm}) / \mathrm{TOM}(\mathrm{ppm})$ & $33-35$ \\
Salinitas $(\mathrm{ppt}) /$ Salinity $(p p t)$ & \\
\hline
\end{tabular}

\section{KESIMPULAN}

Kondisi gonad bulu babi pada musim kemarau (Juli-Oktober) saat stadia berkembang paling tinggi hanya $30 \%$ dari populasi, tetapi pada musim hujan (Nopember-Desember) stadia berkembang mencapai $100 \%$. Hal ini kemungkinan telah terjadi pemijahan secara masal akibat dimulainya musim hujan pada akhir Oktober. Perubahan faktor lingkungan perairan termasuk penurunan salinitas dari 35 ppt ke 33 ppt kemungkinan juga telah memacu pertumbuhan Cymodocea rotundata dan Thalassia hemprichii yang merupakan pakan alami bulu babi tersebut. Selain itu keadaan tersebut telah memacu terjadinya sinkronisasi perkembangan gonad bulu babi, sehingga seluruh sampel gonad bulu babi yang diambil dari perairan Pulau Barang Lompo pada bulan Nopember dan Desember berada pada kondisi gonad berkembang.

Kandungan protein gonad bulu babi pada stadia matang gonad (44,69\%), lebih rendah dibanding kandungan protein gonad bulu babi pada stadia berkembang $(56,68 \%)$. Hal ini kemungkinan pada stadia matang gonad, sebagian kandungan protein gonad telah dirubah menjadi lemak. Ini ditunjukkan dengan kandungan lemak gonad pada stadia matang $(13,16 \%)$ dibandingkan dengan kandungan lemak gonad pada stadia berkembang $(5,73 \%)$.

Perlu adanya pengaturan penangkapan bulu babi terutama hanya dilakukan pada saat kualitas gonadnya baik yaitu dalam kondisi gonad berkembang (Nopember-Desember) dan juga perlu adanya pembatasan jumlah bulu babi yang boleh ditangkap (quota) pada musim panen tersebut, sehingga tekanan terhadap sumber daya bulu babi dapat dikurangi. Dengan demikian diharapkan populasi bulu babi di perairan Kepulauan Spermonde.akan meningkat

\section{DAFTAR PUSTAKA}

Bernard, F. R. 1977. Fishery \& the reproductive cycle of the Red Sea urchin, Strongylocentrotus franciscanus in British Columbia. J. Fish. Res. Board Canada 34: 604.

Chasanah, E., S. Harwanti \& H. Pelu. 1997 Penanganan pascapanen bulu babi Tripneustes gratilla dan kualitas gonadnya. Makalah Seminar Kelautan 24-27 Juni 1997 di Universitas Hasanudin Ujung Pandang. 12 hal.

Chasanah, E \& R. Andamari. 1997. Komposisi kimia, profil asam lemak dan asam amino gonad bulu babi Tripneustes gratilla dan Salmacis sp dan potensi pengembangannya. Prosiding Seminar Kelautan LIPI-UNHAS ke I, Balitbang Sumber Daya Laut Puslitbang Oseanologi LIPI Ambon, Maret 1998. Hal: 269274.

Darsono, P. 1983. Beberapa aspek biologi bulu babi Diadema setosum (Leske) di terumbu karang Pulau Pari-Pulau Pulau Seribu. Thesis Program Sarjana Biologi, Fakultas Biologi Universitas Nasional Jakarta. 85 hal. 
Darsono, P \& Sukarno. 1993. Beberapa aspek biologi bulu babi, Tripneustes gratilla (Linnaeus) di Nusa Dua Bali. Oseanologi di Indonesia 26: $13--25$.

Dinas Perikanan Dati I Propinsi Bali. 1985. Pelaksanaan Pembangunan Subsektor Perikanan Daerah Tingkat I Bali selama tahun 1984/1985. 15 hal.

Fuji, A. 1960. Studies on the biology of the sea urchin I. Superficial and histological gonadal changes in gamet oogenic process of two sea urchins, Strongylocentrotus nudus and S. intermedius. Bull. Fac. Fish. Hokkaido Univ. $11(1): 1--14$.

Giese, A. C. \& Pearse, J. S. 1974. reproduction of marine invertebrates vol. 1. Acoelomate and Pseudocoelomate Metazoans. Acad. Press, New York. Hal. 9.

Juinio-Menez, M. A., Makawaris, N. N. D \& Bangi, H. G. P. 1998. Community-based sea urchin (Tripneustes gratilla) grow-out culture as a resource management tool. In: G. S. Jamieson and A. campbell (Eds). Proceeding of the North Pacific Symposium on Inverte Barangate Stock Assessment and Management. Edited by. Can. Spec. Publ. Fish. Aquat. Sci. 125: 393--399.

Gunarto \& T. M. Wong. 1994. Gonadal cycle of Crassostrea belcheri sowerby under different salinity regimes. In: Chou et al. (Eds.).
Proceeding of the Third Asian Fisheries Forum. The Asian Fisheries Society Manila, Philippines. Hal. 932--935.

Lovell, R. T. 1981. Laboratory manual for fish feed analysis and fish nutrition studies. Department of Fisheries and Allied Aquacultures. International Center for Aquaculture. Auburn University. 65 hal.

Nontji, A. 1987. Laut Nusantara. Penerbit Djambatan, Jakarta. 368 hal.

Sigid, H., Suryodiputro, I. N. N., \& B. Widigdo. 1992. Limnologi: Penuntun Praktikum dan Metode Analisa Air. Institut Pertanian Bogor. Fakultas Perikanan. 57 hal.

Starr, M. \& J. H. Himmelman. 1993. Environmental control of green sea urchin, Strongylocentrotus droebachiensis, spawning in the St. Lawrence Estuary. Can. J. Fish. Aquat. Sci. 50: 894--901.

Tuwo, A. 1995. Aspek biologi bulu babi jenis Tripneustes gratilla di Pulau Kapoposang, Dati II Pangkep, Sulawesi Selatan. Oseana. 20(1): 21--29.

Tuwo, A \& U. Pelu. 1997. Biologi reproduksi bulu babi Tripneustes gratilla. In: Wenno, L. F., A. Noor, Sigit, A. P. Dwiono, R. Syamsuddin \& N. $N$. Wiadnyana (eds.) Prosiding Seminar Kelautan LIPI-UNHAS ke I. Balitbang Sumber Daya Laut. Puslitbang Oseanologi-LIPI Ambon. Hal. 1--3. 


\section{Lampiran}

Appendix

Tabel 1. Penetapan stadia gonad bulu babi ( $T$. gratilla) berdasarkan modifikasi kriteria dari Fuji (1960)

Table 1. The Gonadal stages determination of sea urchin (T. gratilla) based on modification from Fuji (1960)

\begin{tabular}{ll}
\hline $\begin{array}{l}\text { Stadia } \\
\text { Stages }\end{array}$ & $\begin{array}{l}\text { Penampakan mikroskopik gonad } \\
\text { Gonad microscopic feature }\end{array}$ \\
\hline Berkembang & $\begin{array}{l}\text { Gonad sedang dalam awal perkembangan, oosit atau spermatosit melekat pada } \\
\text { germinal epitel dan mulai berkembang, sel-sel nutritive phagosit masih dalam } \\
\text { rongga follikel }\end{array}$ \\
Develop & $\begin{array}{l}\text { The gonadal at the beginning to develop, oocyte or spermatocyte attached in the } \\
\text { germinal epithel and started to develop, nutritive phagocyte cell still in follicle } \\
\text { lobule }\end{array}$ \\
Matang & $\begin{array}{l}\text { Oosit berkembang menjadi ootid dan spermatosit menjadi spermatit. Sebagian } \\
\text { ova atau spermatozoa mengisi lumen atau bahkan lumen penuh dengan ova atau } \\
\text { spermatozoa }\end{array}$ \\
Mature & $\begin{array}{l}\text { Oocyte develop to ootide and spermatocyte develop to spermatide. A part of the } \\
\text { ovum or spermatozoa fill of the lumen or even the lumen full with ovum or } \\
\text { spermatozoa }\end{array}$ \\
Memijah & $\begin{array}{l}\text { Sebagian ova atau spermatozoa telah dikeluarkan, sebagian lumen kosong, sel } \\
\text { nutritive phagosit berkembang dan mereduksi sisa-sisa gamet }\end{array}$ \\
Spawned & $\begin{array}{l}\text { A part of the ovum or spermatozoa have spawned- out of the lumen, a part of the } \\
\text { lumen empty, the nutritive phagocyte cell started to develop and reduce the rest } \\
\text { of gamet cell }\end{array}$
\end{tabular}

